\title{
The Importance of Nutrients Concentration Monitoring In Coastal Area
}

\author{
Wisnu Arya Gemilang*, Ulung Jantama Wisha and Ruzana Dhiauddin
}

\author{
Research Institute of Coastal Resources and Vulnerability \\ Ministry of Marine Affairs and Fisheries, Republic of Indonesia \\ Jl. Raya Padang Painan km 16, Padang, Sumatera Barat, 25245 Indonesia \\ Email: wisnu.gemilang@yahoo.co.id
}

\begin{abstract}
Land utilization changes of the natural resources conservation area of Pangandaran coastal area, that have been utilized as a marine tourism area, which affect many kinds of environmental degradation threats. Updating the condition of Pangandaran waters is essential due to its condition impacted by anthropogenic activities. Water condition monitoring was done by measuring nutrients as an indicator to assess the water fertility and pollution. Fourty five observation points were selected and divided into three locations, representing the condition of river, estuary/mangrove area, and open sea. Nutrients were analyzed by employing Standard Methods for The Examination of Water and Wastewater 22 ${ }^{\text {nd }}$ Edition 2012 (SMEWW). Currents and tides were measured for 15 days, used as the basis input of hydrodynamic model. The results showed that the highest of average value of nitrate was found in the estuary/mangrove forest which reached $0.998 \mathrm{mg.L} \mathrm{L}^{-1}$. While, the highest phosphate content was observed in the river which reached $0.928 \mathrm{mg} . \mathrm{L}^{-1}$. The highest ammonia concentration was observed in the sea which reached $0.027 \mathrm{mg} . \mathrm{L}^{-1} . \mathrm{N}: \mathrm{P}$ ratios in the study area are categorized $<16$, which showed that Pangandaran waters are in the condition of $N$-limitation. These conditions trigger blooming of phytoplankton due to the high concentration of nitrate. The higher nutrient concentration indicates that anthropogenic activities take place. Tidal current has an important role transporting nutrient in the estuary, triggering nutrient deposition and blooming tendency. Restrictions on residential areas and the utilization of coastal areas are an appropriate step to reduce the pollution level in Pangandaran waters.
\end{abstract}

Keywords: monitoring, water quality, pollution, nutrient

\section{Introduction}

Coastal area has an important role in maintaining the function of ocean ecosystem. This area is a strategic transition zone where terrestrial and oceanic dynamics factors are both determine the diversity of natural resources. It also enucleates a complex interaction affected by natural and anthropogenic pressure. The impact of those factors correlated with physical and biological process of the coastal area (Calvão et al., 2013), while the river discharge is a physical factor determining dynamics occurrence in the coastal area (Romero et al., 2013). Changes accumulation of climate, population, industrialization, and agriculture may change the river mouth and coastal prolificacy (Rabalais et al., 2009).

The unbalance of the discharge such nitrogen (N) and phosphor $(\mathrm{P})$ are related with the human activity along the watershed. These matters are nonsiliceous source triggering the alga blooming in the river and coastal waters (Seitzinger et al., 2010; Howarth et al., 2011). Most of the nitrogen (N) came from the excessive use of organic or artificial peat in agriculture (De Vries et al., 2011) that according to Zhang et al. (2015) that the anthropogenic factors donate 3 times nitrogen onto coastal ecosystem comparing to industrial. Meanwhile, the organic waste still considered as a main source of phosphor (P) even the water purification had been applied (Passy et al., 2013).

Human activity globally is more potential impacting nitrogen enhancement to coastal ecosystem than industrial activities (Zhang et al., 2015) Pangandaran regency is located in the southeast part of West Java which has various potential in tourism aspect. Several tourism objects in this region has widely well known by domestic and international community, such as tourism object of Pangandaran beach (Sewiko, 2016). The land utilization of tourism and aquaculture impacts the landuse changes which evoke several environment threats. Tourism is one of the focal economic action corresponding to the landuse and landcover (Wang and Liu, 2013).

Environmental pollution occurred in the area of settlement, tourism, and industry near the coast is 
caused by disposal household and industrial waste which contains chemical materials. It induces the changes of ecological condition (Rositasari et al., 2011). The discharge of those disposal waste causes the water quality degradation which showed by the increasing of nutrients (Utami et al., 2012). The increasing of nutrients in the water has a positive impact such as supporting the photosynthesis production by phytoplankton which directly will enhance the fisheries resources, however, in the specific level, it will be negatively impact as well such as declining the dissolved oxygen in the water due to algal blooming and trigger the growth of harmful algal (harmful algal blooms) (Gypens et al., 2009).

Organic materials and nutrients from river which enters to the coastal waters largely has a significance role in biology processes stimulation in those waters (Chou et al., 2013). The increasing of nutrients caused by upwelling, anthropogenic source and river discharge influences the growth of phytoplankton in the coastal area (Neale et al., 2014). The major nutrients which need to be controlled are nitrate and phosphate. Those nutrients have a big role in phytoplankton growth which are used for chemical indicator to assess the level of water fertility (Garmendia et al., 2013). In addition, according to Risamasu and Prayitno (2012) nitrate and phosphorus control the growth and metabolism of phytoplankton, which is macro nutrients and useful as a limiting nutrient for phytoplankton growth (Thakur et al., 2013).

A lot of rivers disembogued in the Pangandaran coastal area is one of significant factors of disposal waste in the waters. Besides that, the hydro-oceanography factors as well as its location adjacent with Indian Ocean affect this area characterized by strong currents which directly influence the distribution of nutrients in the east coast of Pangandaran waters. That condition causes wastes sourced from land flows in the river, when it touched the estuary, it will be separated and distributed as well. Based on the issues above, it is severe necessary conducting a research regarding the issues occurred. Particularly, to know the recent condition of nitrate, ammonia, and phosphate contents in the waters of Pangandaran, so that can be an information and a reference in an effort to monitor the fertility of the waters.

\section{Materials and Methods}

Study area is located in Pangandaran Sub District, West Java. This study focuses on east coast of Pangandaran. Geographically, study area is positioned at $7^{\circ} 40^{\prime} 11.44^{\prime \prime} \mathrm{S}$ - $108^{\circ} 37^{\prime} 49.25^{\prime \prime}$ and $7^{\circ} 43^{\prime} 48.75^{\prime \prime S}$ - $108^{\circ} 37^{\prime} 52.67^{\prime \prime E}$. East coast of Pangandaran is a center of tourism, settlement, and fish auction. Observation area was separated by 3 zones of sampling including zone A (river), zone B (estuary and mangrove area), and zone $C$ (coastal and sea). Those zones were chosen to observe the nutrient concentration on each zone by considering three significance zones of nutrient transport potential due to tidal current influence.

The primary data were the laboratory analysis result for nutrients from 3 different locations (Figure 1.), which is including phosphate, nitrate, and ammonia compound. Besides that, we also measured water quality, tides, and currents directly in field (in situ). Whilst, the secondary data were consisted of tide forecasting, rainfall intensity, and topography of study area.

The observation point was consisted of 45 points which was conducted for three days. Because of the broad of study area, we divided the area into 3 groups (group A, B, and C) of sampling point which is river, estuary, and sea. Water sampling was done in the condition of low towards high tidal condition (Figure 2.). The sampling time decision was based on the tide forecasting supported by NAOtide, and the correlation of nutrients distribution in the same tidal phase was obtained.

Samples were taken at 17 observation points for group A (river), 10 observation points for group B (estuarine and mangrove ecosystems) and group $C$ (sea water). Sampling is done by using Nansen bottles on the surface at each observation point. The samples were then observed in the Environmental Engineering of Bandung Institute of Technology (ITB) which referred to Standard Methods for The Examination of Water and Wastewater $22^{\text {nd }}$ Edition 2012 (SMEWW).

The determination of nitrate concentration analyzed by employing 4500-NO3-B method. It was Ultraviolet Spectrophotometric Screening Method which only used filtering sample with less of nutrient compound. SMEWW 4500-NH3-F (phenate) was used analyze ammonia which was going through without the distillation stage. Total phosphate compound was analyzed by using SMEWW-4500-PB-D (Stannous Chloride Method) which was applying one of Colorimetric methods. It is more suitable applied for sample with 0.01-6 mg.t-1 P/L concentration.

Water quality measured in the study area by using Water Quality Checker (TOA DKK Type WQC24) and dissolved oxygen (DO), temperature, $\mathrm{pH}$, and salinity data were obtained. Acoustic Doppler Current Profiler (ADCP) was deployed during 1th August $20166.30 \mathrm{AM}-15^{\text {th }}$ August 20161.30 PM 


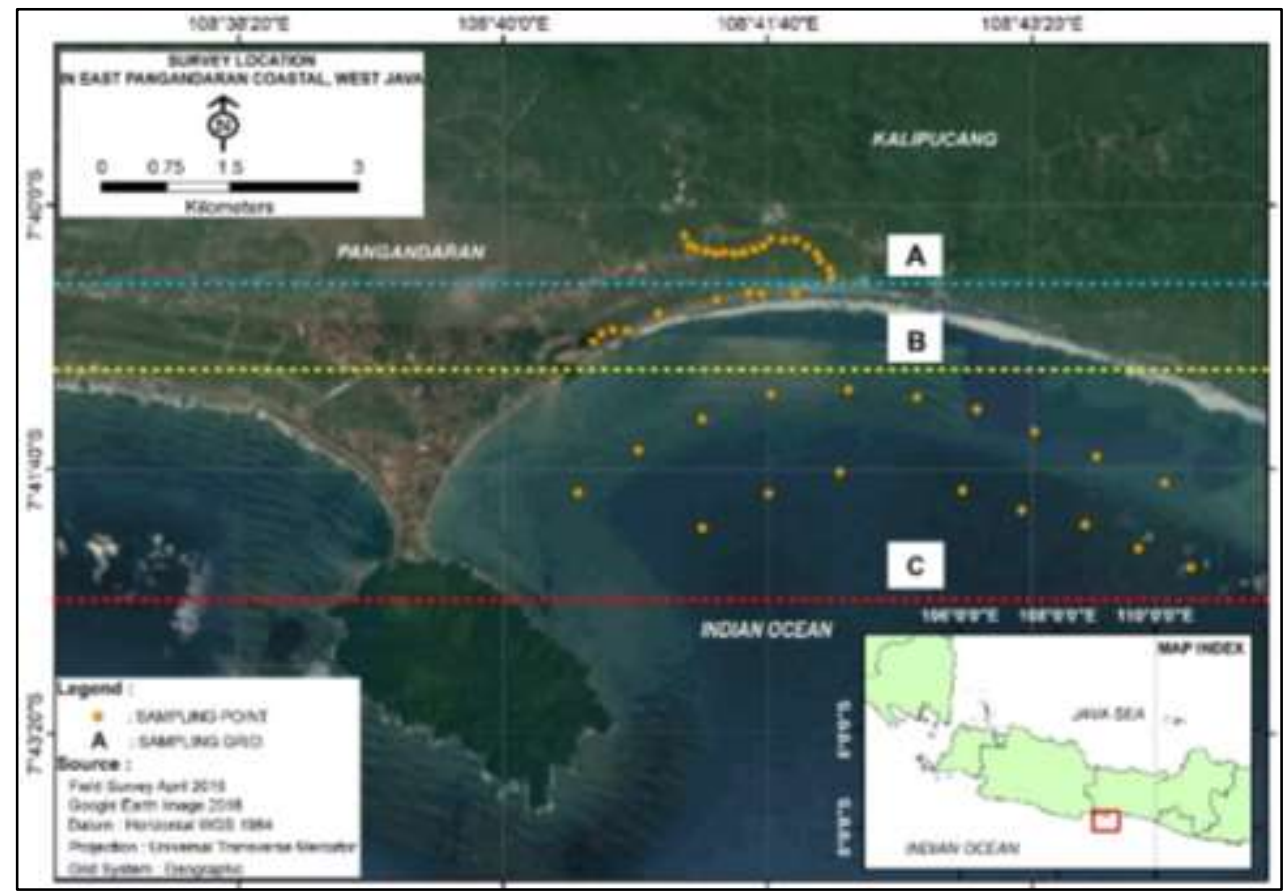

Figure 1. Research location map

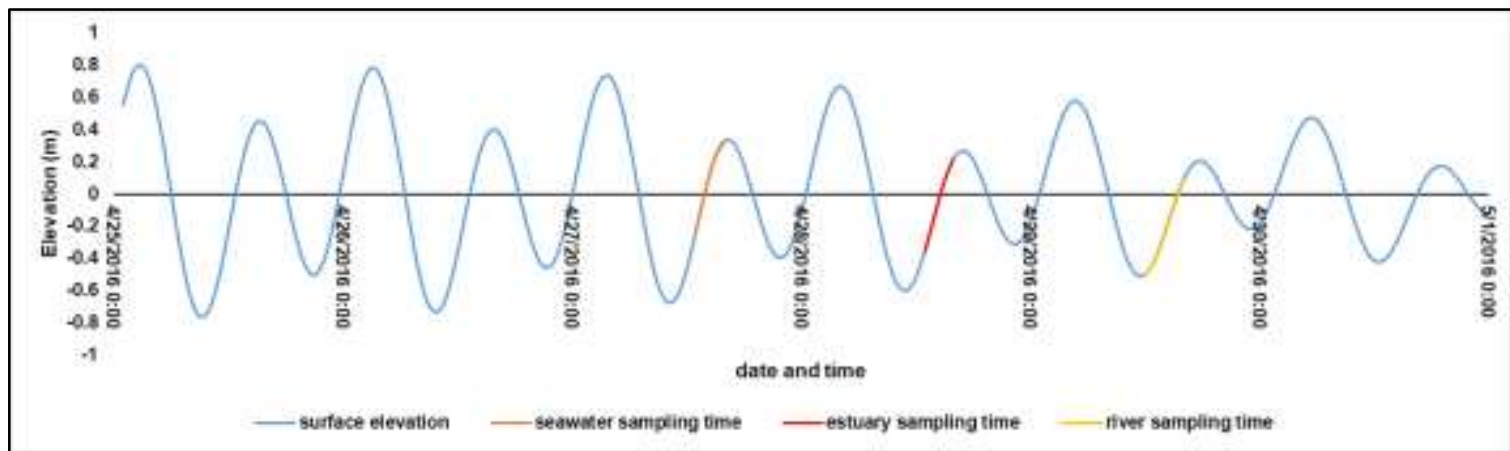

Figure 2. Tide forecasting and sampling time

Table 1. Flow model set-up

\begin{tabular}{|c|c|}
\hline Parameter & Implemented in the simulation \\
\hline \multirow[t]{4}{*}{ Time of simulation } & Number of time step $=1500$ \\
\hline & Time step interval $=900 \mathrm{sec}$ \\
\hline & Simulation start date $=1 / 08 / 201608.00 \mathrm{PM}$ \\
\hline & Simulation end date $=17 / 08 / 201601.00 \mathrm{AM}$ \\
\hline Mesh boundary & $\begin{array}{l}\text { Bathymetry = Pushidrosal map digitation year } 2016 \text { and bathymetry } \\
\text { survey result year } 2016\end{array}$ \\
\hline \multirow[t]{3}{*}{ Flood and dry } & Drying depth $=0.005 \mathrm{~m}$ \\
\hline & Flooding depth $=0.05 \mathrm{~m}$ \\
\hline & Wetting depth $=0.1 \mathrm{~m}$ \\
\hline \multirow[t]{6}{*}{ Boundary condition } & Type = Specified level \\
\hline & Format $=$ Varying in time, constant along boundary \\
\hline & Time Series = Tide forecasting with coordinates below: \\
\hline & 1. Longitude: 108.59168 , Latitude: -7.7243 \\
\hline & 2. Longitude: 108.66633 , Latitude: -7.7649 \\
\hline & 3. Longitude: 108.74041 , Latitude: -7.7254 \\
\hline
\end{tabular}


which covered 15 days of measurement. It was sufficient to represent the cycle of spring and neap tides. The ADCP records several physical data such as tide, temperature, and current. To evaluate the model result, it must be compared with field measurement tides data (Jin and Ji, 2004), applying Root Mean Square Error (RMSE).

Flow model was employed to determine the distribution pattern of nutrients and the other water quality parameters, which mainly are influenced by tidal current and water mass dynamics. Tidal currents simulated for 15 days simulation, but the result will be displayed only during low towards high tidal condition in the neap tidal phase (similar with the date and tidal condition of in situ).

Flow model numeric simulation was employed which shows the result in the form of twodimensional data (Warren and Bach, 1992; Mehdiabadi et al., 2015). The input model employed bathymetry data from Hydrography and Oceanography Center, Indonesian Navy (Pushidrosal) combined with Bathymetry measurement result and digital coastline Google Eye imagery 2016. The surface elevation was obtained by employing ERGtide in the form of time series data. Set-up of hydrodynamic model is shown in Table 1.

\section{Results and Discussion}

Nitrate concentration varies. In the river reaches $0.613 \mathrm{mg} . \mathrm{L}^{-1}$ (Figure 3.), in the estuary reaches $0.998 \mathrm{mg} . \mathrm{L}^{-1}$ (Figure 4.) and in the sea reaches 0.369 mg. L-1 (Figure 5.). Those values show that the highest nitrate concentration is identified in the estuary and mangrove area.

High rate of nitrate concentration in the mangrove forest area and estuary is caused by intake from land through rivers and open sea which settled in the estuary. It is then accumulated in the mangrove area which is the major area of nutrient source. The tidal mechanism also has a big role controlling the transport of nutrient in the estuary. This condition is supported by the high $\mathrm{pH}$ value which triggers the nitrification process. The average of $\mathrm{pH}$ in that area is 8.2 (Table 1.). According to Ganesan et al. (2013) the optimal pH condition to support nitrification process ranges 8-9 which results the high concentration of nitrate, whereas, in the condition of $\mathrm{pH}<6$ the reaction will be stalled.

The average of $\mathrm{pH}$ value in the mangrove forest area which has reached 8.2. it triggers the nitrate concentration enhancement. Besides that, the salinity value in Pangandaran waters which has

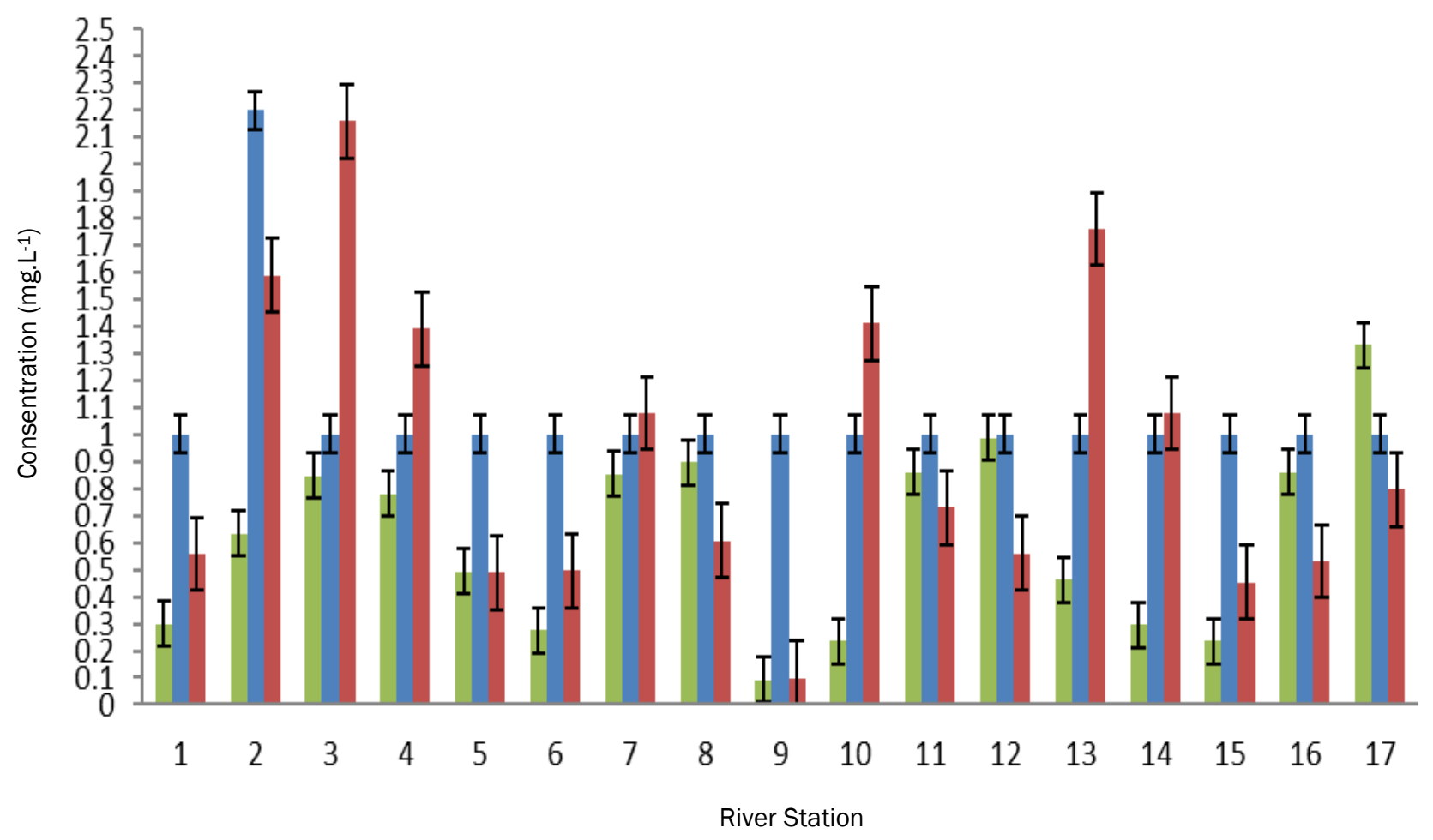

Figure 3. Nitrate, phosphate and ammonia concentrations (river station) Note. $=$ Nitrate $\left(\mathrm{mg} . \mathrm{L}^{-1}\right) ; \quad=$ Ammonia $\left(\mathrm{mg} . \mathrm{L}^{-1}\right) \times 10^{-2} ; \mathbf{\square}=$ Phospate $\left(\mathrm{mg} . \mathrm{L}^{-1}\right)$ 


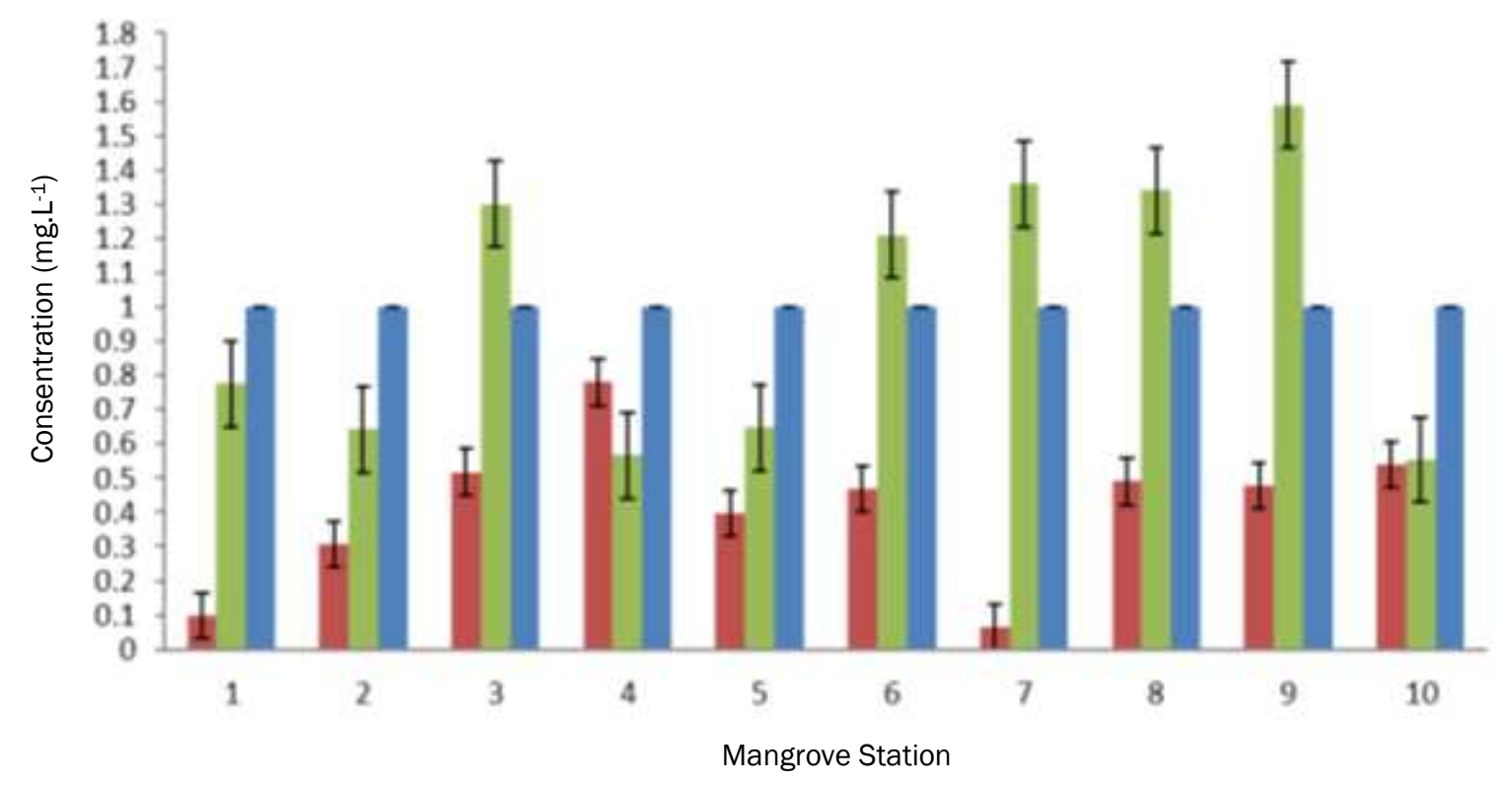

Figure 4. Grafik kosentrasi nitrate, phosphate dan ammonia (mangrove station)

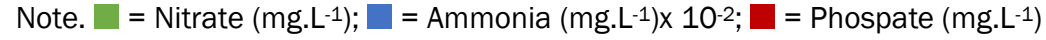

Tabel 2. The average value of water quality data

\begin{tabular}{cccc}
\hline Parameter & River & Estuary/Mangrove & Sea \\
\hline $\mathrm{pH}$ & 7.92 & 8.21 & 8.49 \\
Salinity $(\%)$ & 0.7 & 16.54 & 32.38 \\
DO $\left(\mathrm{mg}^{-1}{ }^{-1}\right)$ & 47.27 & 38.43 & 41.49 \\
Temperature $\left({ }^{\circ} \mathrm{C}\right)$ & 28.69 & 32.26 & 31.38 \\
TDS $\left(\mathrm{gL}^{-1}\right)$ & 1.15 & 24.69 & 52.91 \\
\hline
\end{tabular}

reached 32.38 (Table 2.) also has a big role in controlling nitrate concentration in the water. According to Parihar et al. (2015) nitrate concentration will deteriorate in accordance with salinity enhancement.

The average value of total $P$ in the three measurement locations shows that total $P$ in the river is the highest reaching $0.928 \mathrm{mg} . \mathrm{L}^{-1}$. While, in the sea and estuary, total $P$ reaches 0.489 mg. $L^{-1}$ and 0.413 mg. $\mathrm{L}^{-1}$ respectively. In generally, open sea has a poor content of phosphate which naturally the nutrients are transported from the surface to bottom and the cycle was recurred in the form of biogeochemical cycle. The deeper of water, the more that compound found due to the high rate of nutrient settling in the water. The concentration will decline in accordance with the decreasing depth (surface) (Simanjuntak, 2012). Besides that, the low phosphate concentration in the surface is caused by the intensive phytoplankton activity to produce the energy (photosynthesis) (Kress et al., 2014).

Phosphate concentration tend to be lower than the other nutrients due to few dump and waste discharge from the rivers (Dewi et al., 2017). Local people utilized upstream area as settlement and agriculture area which has become the major source of nutrient waste. One of that sources is nitrogen compound resulted from agricultural fertilizer waste which enters into the river through the drainage system and it is then transported and accumulated in the estuary (Kataki et al., 2016). It is obvious why in the estuary is found a high level of phosphate compound.

The high value of phosphate is also influenced by mangrove vegetation which results the abundance of nutrients due to its leaves remnants which are decomposed by decomposer bacteria.it becomes the main source of detritus (Mustofa, 2015). Its degradation product is then becoming nutrients such as phosphate, nitrate, sulphur, and the other compounds (Lau, 2013). Nitrogen (N) and phosphorus $(\mathrm{P})$ are the main nutrients controlling eutrophication and blooming tendency. $\mathrm{N}: \mathrm{P}$ ratio becomes an index representing the limitation of nutrients which supports algal growth in the water (Chen et al., 2013). 
The comparison of nutrients composition average assimilating into algal usually is called as Redfield ratio (Fujimoto et al., 1997). The result of $\mathrm{N}: \mathrm{P}$ ratio calculation in the three observation areas shows a significant variation value (Figure 6). The average of $\mathrm{N}: \mathrm{P}$ in the river reaches 0.87 , in the estuary reaches 2.73 , whilst, the highest $\mathrm{N}: \mathrm{P}$ ratio average is in the sea reaching 3.2. According to Geider and La Roche (2002) phytoplankton in the condition of N-limited when the N:P ratio $<16$ and $\mathrm{P}$ limited when the N:P ratio $<16$ based on Redfield ratio (Redfield, 1934).

$\mathrm{N}: \mathrm{P}$ ratio in the study area is included into $\mathrm{N}: \mathrm{P}<16$, so can be concluded that in east coast of Pangandaran is in the condition of $\mathrm{N}$-Limited. That condition indicates that the water has the low nitrate concentrations compared with phosphate concentration. A natural ratio of $\mathrm{N}: \mathrm{P}$ in the water should be 16:1 to be used for phytoplankton growth (Effendi, 2003). Nitrate concentration reaches 0.32 , 0,98 , and $0,56 \mathrm{mg} . \mathrm{L}^{-1}$ in the sea, estuary, and river, respectively.

When nitrate concentration is more than 0.2 mg. $\mathrm{L}^{-1}$, it can potentially cause eutrophication which then rapidly triggers algal growth (blooming) (Tungka et al., 2017). According to the results, nutrients in Pangandaran east coast potentially experiences blooming of phytoplankton due to the value of nitrate $>0.2 \mathrm{mg} . \mathrm{L}^{-1}$. Eutrophication process can damage the ecosystem because the oxygen supply is either reduced or anoxic. As a result, those condition can disrupt the marine life in the surrounding (van der Wulp et al., 2016)

Based on standard quality of MENLH No. 51, 2004 , stated that the standard quality of maximum several nutrient concentrations which is suitable for marine life is varied (Table 3). The result shows nitrate and phosphate content exceed the required concentration limits. While, the ammonia concentration is in the permissible range until it is still safe for marine life. The increasing nitrate in Pangandaran waters indicates that it experiences pressure in the form of nitrogen (nitrate) enrichment. It impacts the algal blooming tendency potential which influences the ecosystem health and biodiversity regionally (Risamasu and Prayitno 2012).

Nitrate concentration in the east coast of Pangandaran exceeds the standard quality established by MENLH No. 51, 2004. This condition might be caused by dumping waste from landsources as well as the agricultural waste. Those two factors give a significant role triggering the high concentration of nitrate in Pangandaran waters.

Vertical profile of current velocity component in $U$ direction (East) shows that the speed enhances from 14-7 meters depth, which becomes slower and stable in the surface. In V direction (North), current speed increases in the same layer as $U$ velocity but it

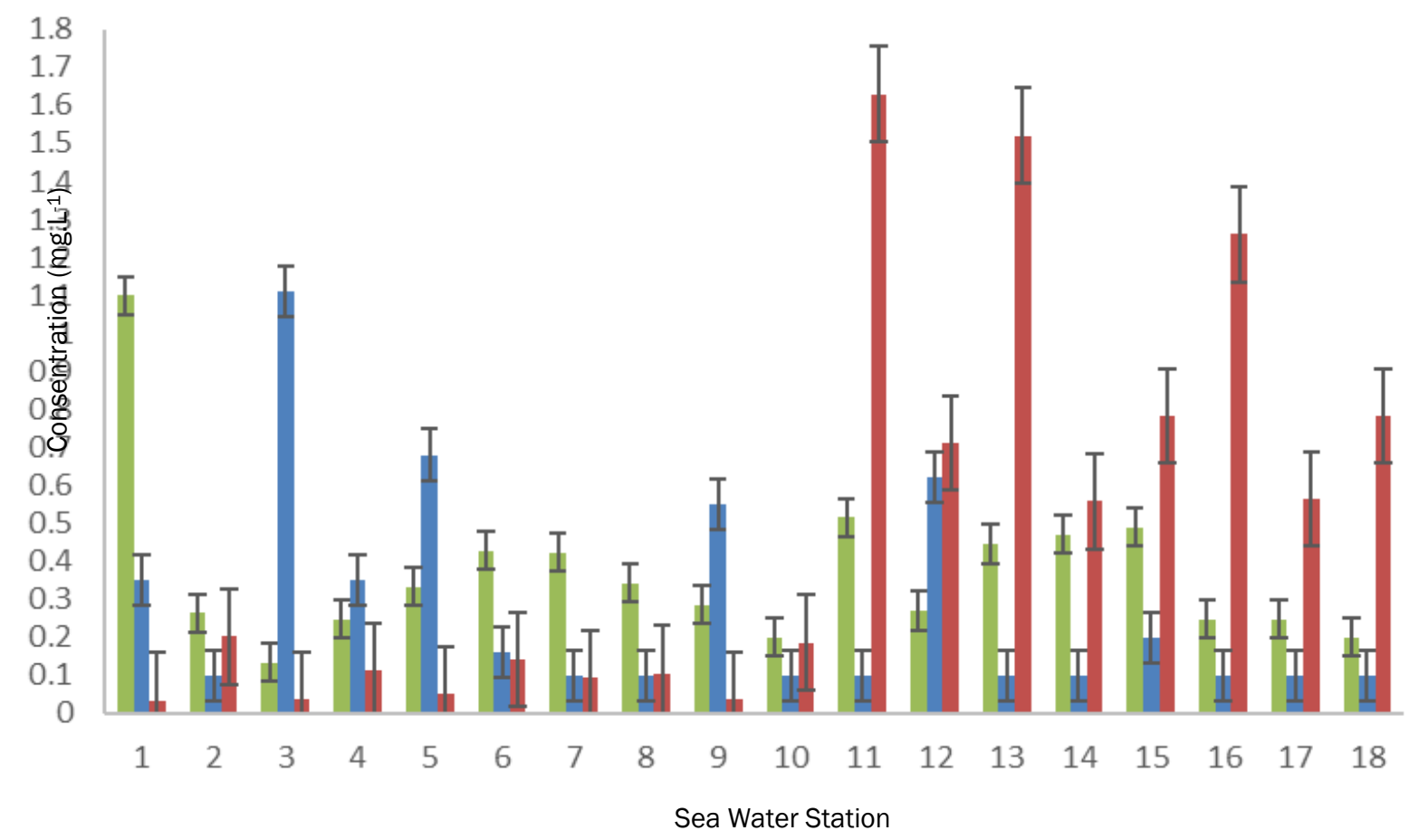

Figure 5. Nitrate, phosphate, and ammonia concentrations (sea water station)

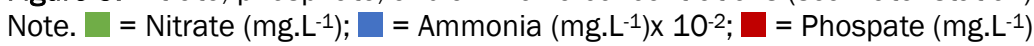



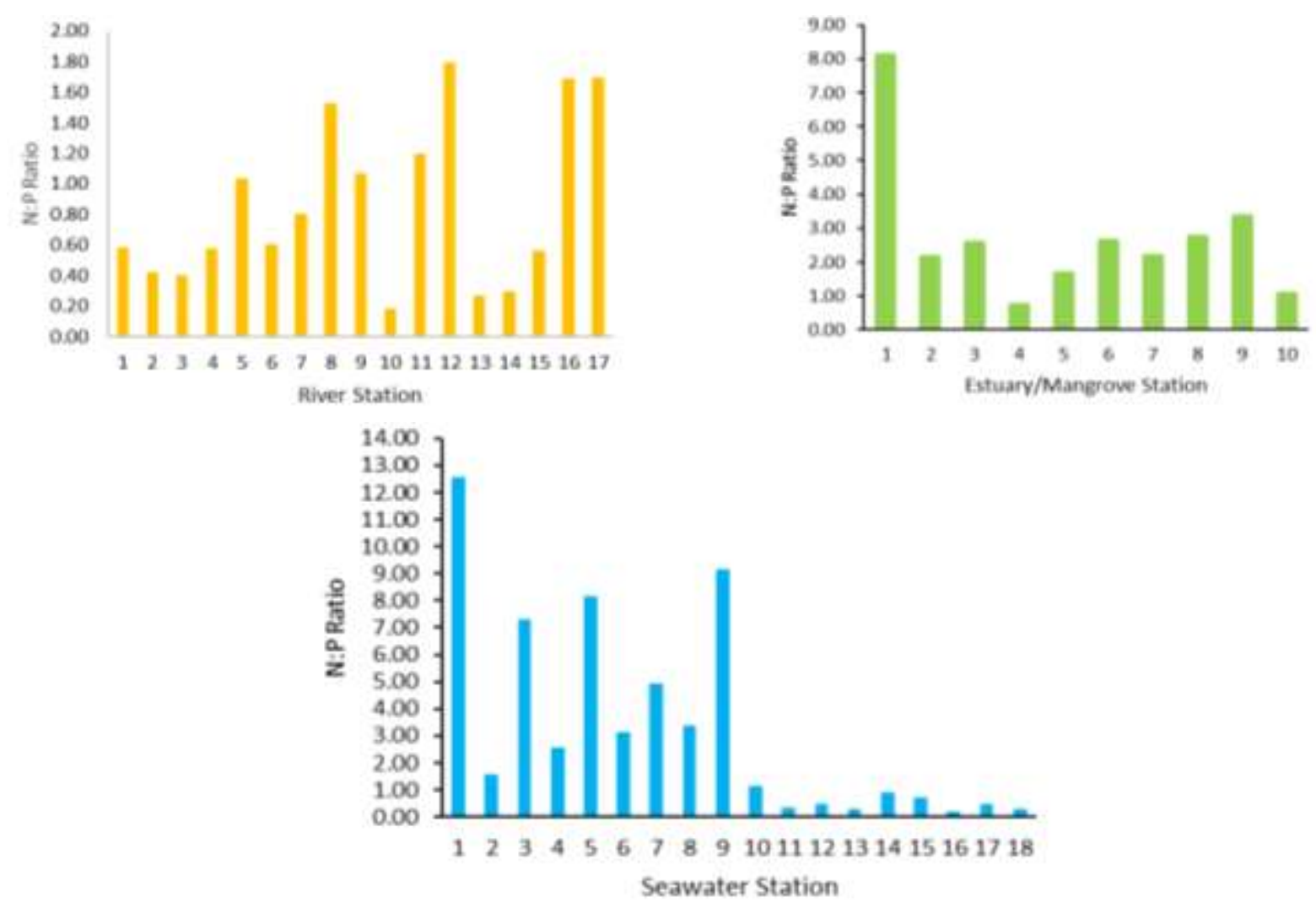

Figure 6. The graph of N:P ratio in the three observation areas
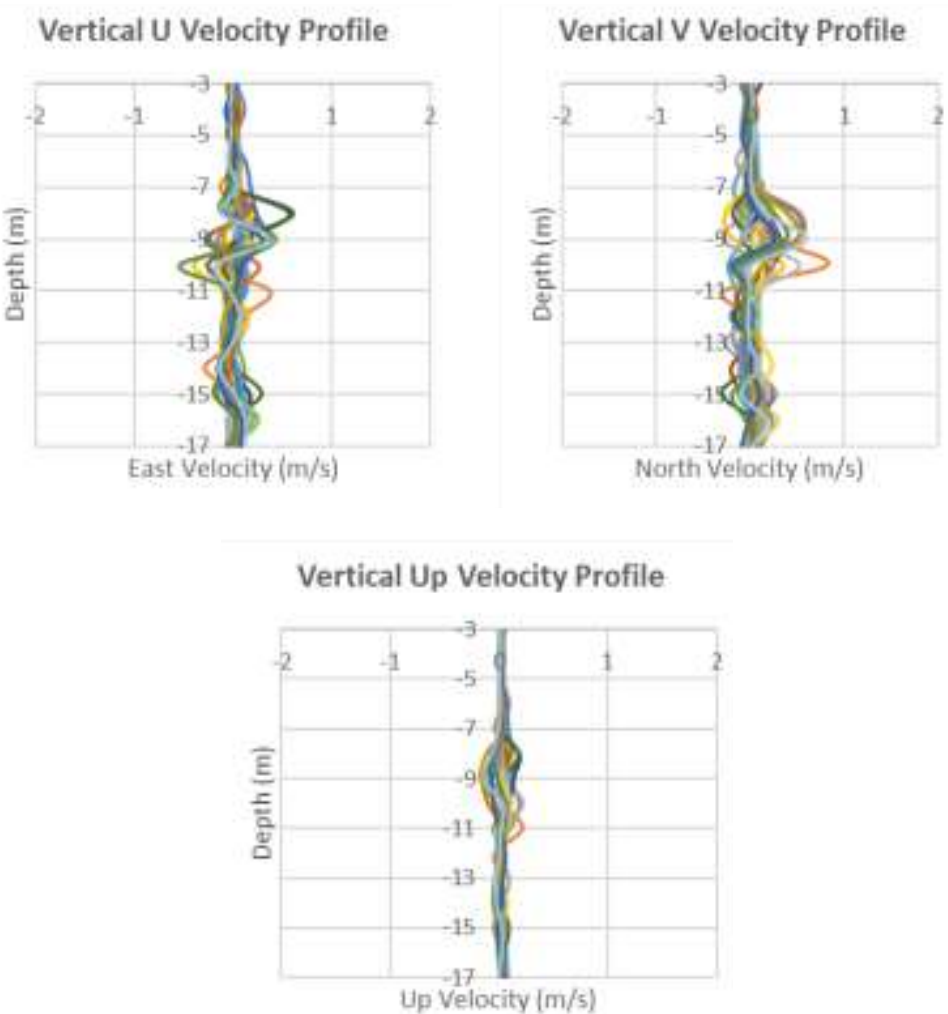

Figure 7. Current velocity component profiles based on ADCP measurement 


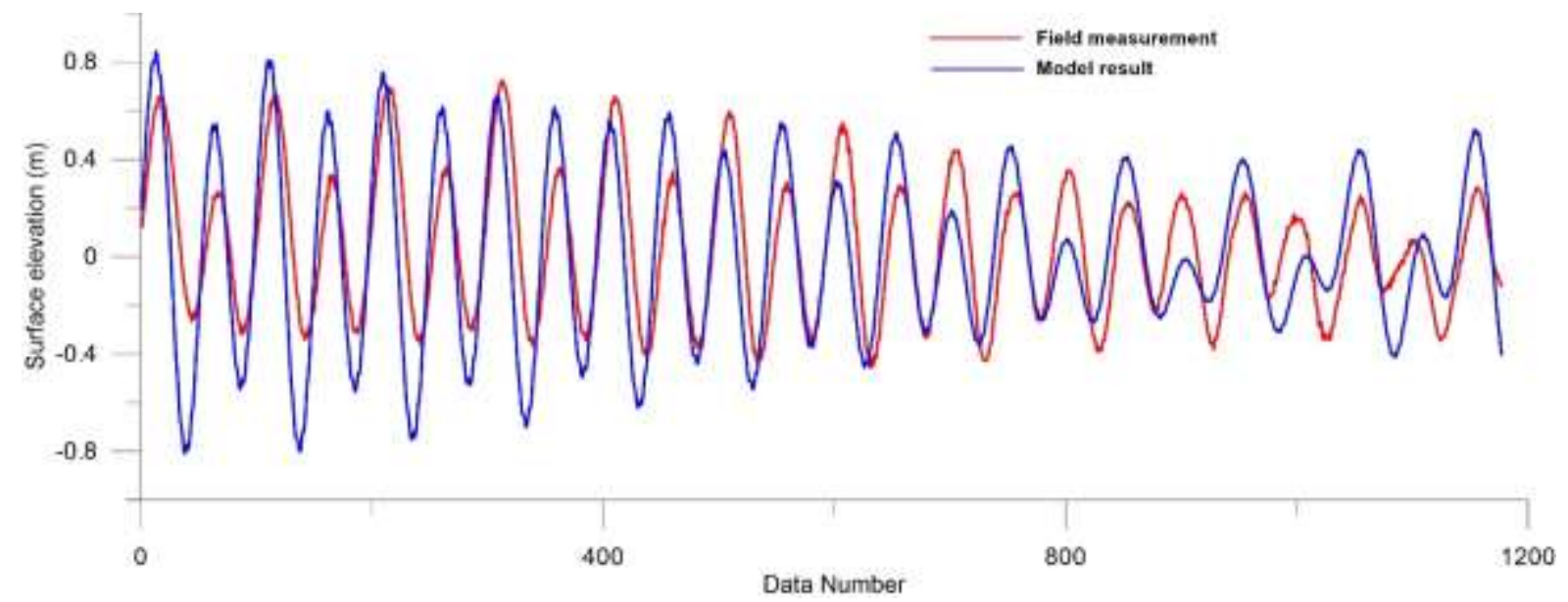

Figure 8. Model validation using surface elevation data

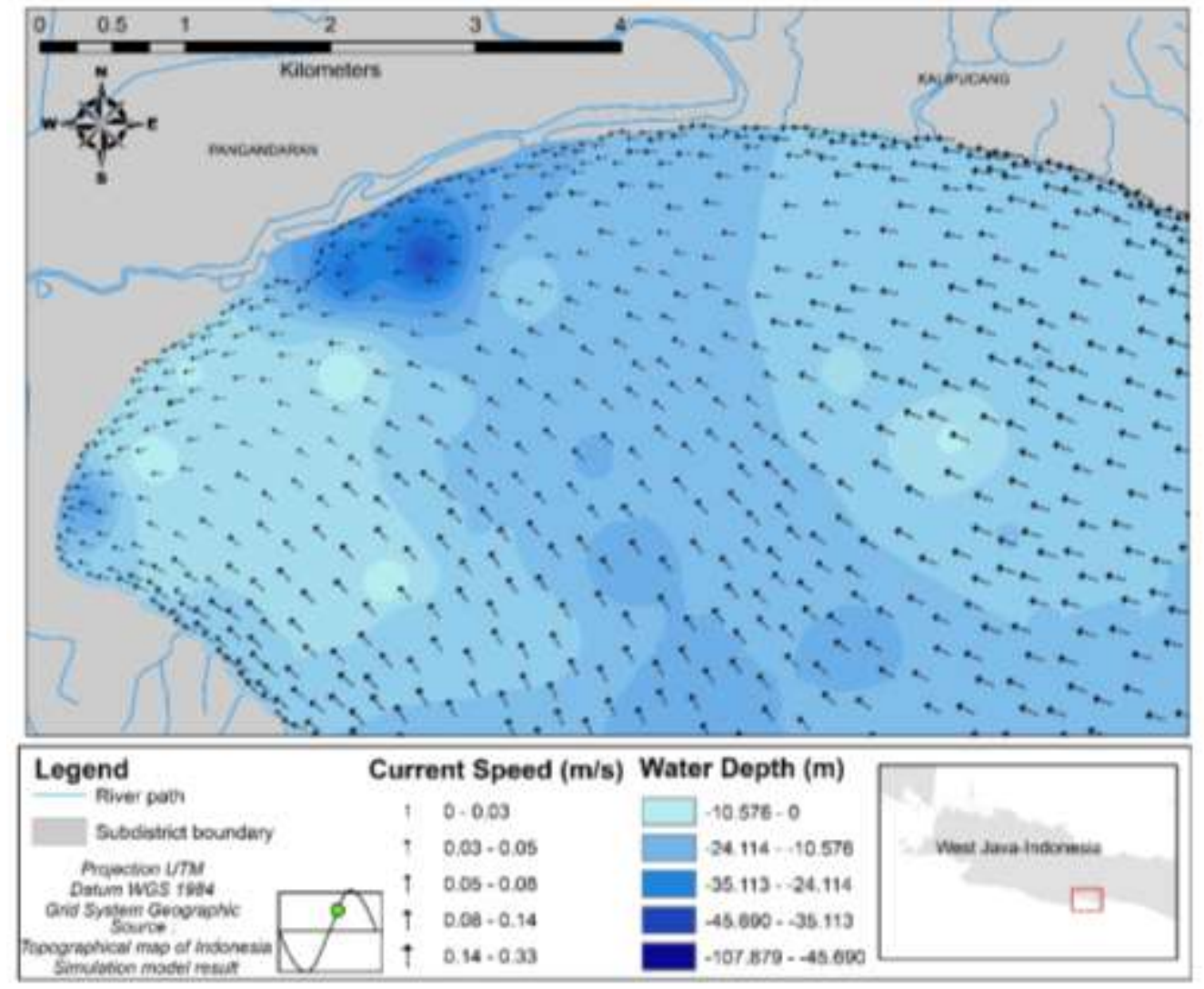

Figure 9. Tidal current pattern during high toward low tidal condition

Tabel 3. Nitrate, phosphate and ammonia compared with standard quality of KemenLH, 2004

\begin{tabular}{lccccc}
\hline \multicolumn{1}{c}{ Parameter } & River & $\begin{array}{c}\text { Estuary/Mangrove } \\
\text { forest }\end{array}$ & Seawater & $\begin{array}{c}\text { Sea water standard } \\
\text { quality } \\
\text { (KemenLH, 2004) }\end{array}$ & $\begin{array}{c}\text { River standard quality } \\
\text { (KemenLH, 2004) }\end{array}$ \\
\hline Nitrate (mg.L-1) & $0.09-1.33$ & $0.55-1.59$ & $0.13-1.10$ & 0.008 & 1 \\
Phosphate (mg.L-1) & $0.10-2.16$ & $0.06-7.55$ & $0.03-1.63$ & 0.015 & - \\
Ammonia (mg.L-1) & $0.01-0.02$ & 0.01 & $0.01-0.51$ & 0.3 & 2 \\
\hline
\end{tabular}


is slightly fluctuated compared with $U$ velocity. While, Up velocity shows that the vertical transport speed is not to significant and relatively stable (Figure 7 ). Vertical transport velocity is influenced by physical and climatic factors such as tides, waves, monsoon, and ocean oscillation, occurred in the Southern waters of Pangandaran (Susanto et al., 2001). It induces upwelling and downwelling events, triggering the transport of nutrient in the waters vertically.

The largest intake of nutrients derived from the river mouth. At high tidal condition, surface elevation id higher, resulting in the seawater domination in estuary. Whereas, at low tidal condition, surface elevation is lower than river water level, the river discharge will predominate in the estuary. This mechanism occurs in the estuarine areas and the nutrients are transported tidally and affect the degradation of estuary environment (Wisha and Heriati, 2016). Tidal current pattern still in the condition of displacement from ebb to flood, which has begun to enter the coast, from southeast to northwest and perpendicular to the estuaries of Pangandaran coast. It induces the turbulence on bottom particles due to the movement of longshore and rip currents, eventually suspended and floated in the water column (Ondara and Wisha, 2016). The particles are consisted of nutrient compounds and several organic-inorganic matters which are transported by the currents.

Hydrodynamic model simulated during the displacement of low toward high tidal condition at the same time of sampling. The RMSE obtained is $13.76 \%$. The comparison between model and field survey of surface elevation data is shown in Figure 8 , representing the same tidal phase but have different elevation values. The longshore current velocity near the coast is weaker and become the drift transport in the coastal areas (Wisha et al., 2015). The current speed ranged $0-0.3$ m.s $\mathrm{s}^{-1}$ (Figure 9). Tidal current movement is one of the dominant factors in the distribution of dissolved substances and compounds in the waters (Wisha and Heriati, 2016), Its fluctuation changed depended on tidal condition. It is obvious why the estuarine area has become the nutrients bank, because it is located in the intertidal area where the nutrients transported trapped and settled in that area. If ongoing, the nutrients will trigger blooming tendency and influence water quality degradation which eventually inhibits biota survival ability.

\section{Conclusion}

Nutrient condition in Pangandaran waters is alarming because it has exceeded the quality standards of marine waters and rivers. The highest concentration is found in the estuary which is the bank of nutrient due to its location in the intertidal area. This condition is tremendously pernicious evoking blooming tendency and anoxic condition, which eventually inhibit biota survival ability. Based on N/P ratio, primary productivity of Pangandaran waters is commonly limited by $\mathrm{N}$, where the highest $\mathrm{N} / \mathrm{P}$ value is found in the estuary. Nitrate enhancement in Pangandaran waters indicates that it experiences pressure in the form of nitrogen (nitrate) enrichment. Tidal current has a big role evoking nutrient transport in estuary which is the major factor of organic and inorganic compounds in the water. During the displacement elevation of ebb to flood, nutrients from rivers (household and pollution waste) are disembogued in the estuary, on the other hand, nutrients come from open sea starts to enter the estuary. The results of this study show the importance of sustainable monitoring of water quality in coastal area.

\section{Acknowledgement}

Our deepest gratitude to Research Institute for Coastal Resources and Vulnerability on DIPA 2016 research budget in Pangandaran, West Java, and all those who have assisted in the completion of this scientific paper.

\section{References}

Calvão, T., Pessoa, M.F. \& Lidon, F.C., 2013. Impact of human activities on coastal vegetation-a review. Emirates J. Food Agricul. 25(12):926. doi: 10.9755/ejfa.v25i12.16730.

Chen, N., Peng, B., Hong, H., Turyaheebwa, N., Cui, S. \& Mo, X., 2013. Nutrient enrichment and N: $P$ ratio decline in a coastal bay-river system in southeast China: the need for a dual nutrient ( $N$ and P) management strategy. Ocean Coast. Manag. 81:7-13. doi: 10.1016/j.ocecoaman. 2012.07.013.

Chou, W.C., Gong, G.C., Cai, W.J. \& Tseng, C.M., 2013. Seasonality of $\mathrm{CO} 2$ in coastal oceans altered by increasing anthropogenic nutrient delivery from large rivers: evidence from the Changjiang-East China Sea system. Biogeosci. 10(6):3889. doi: 10.5194/bg-10-3889-2013.

De Vries, F.T., Van Groenigen, J.W., Hoffland, E. \& Bloem, J., 2011. Nitrogen losses from two grassland soils with different fungal biomass. 
Soil Biolog. Biochem. 43(5):997-1005. doi: 10.1016/j.soilbio.2011.01.016.

Dewi, N.N.D.K., Dirgayusa, I.G.N.P. \& Suteja, Y., 2017. Kandungan Nitrat dan Fosfat Sedimen serta Keterkaitannya dengan Kerapatan Mangrove di Kawasan Mertasari di Aliran Sungai TPA Suwung Denpasar, Bali. J. Mar. and Aqua. Sci. 3(2):180-190.

Effendi, H., 2003. Telaah kualitas air, bagi pengelolaan sumber daya dan lingkungan perairan. Kanisius. 258pp.

Fujimoto, N., Sudo, R., Sugiura, N. \& Inamori, Y., 1997. Nutrient-limited growth of microcystis aeruginosa and phormidium tenue and competition under various $\mathrm{N}$ : $\mathrm{P}$ supply ratios and temperatures. Limnol. Oceanograp, 42(2): 250-256. doi: 10.4319/lo.1997.42.2.0250.

Ganesan, P., Kamaraj, R. \& Vasudevan, S., 2013. Application of isotherm, kinetic and thermodynamic models for the adsorption of nitrate ions on graphene from aqueous solution. J. Taiwan Institute Chem. Eng. 44(5): 808-814. doi: 10.1016/j.jtice.2013.01.029.

Garmendia, M., Borja, Á., Franco, J. \& Revilla, M., 2013. Phytoplankton composition indicators for the assessment of eutrophication in marine waters: present state and challenges within the European directives. Mar. Poll. Bull, 66(1-2):716. doi: 10.1016/j.marpolbul.2012. 10.005.

Geider, R.J. \& La Roche, J., 2002. Redfield revisited: variability of $\mathrm{C}$ [ratio] $\mathrm{N}$ [ratio] $\mathrm{P}$ in marine microalgae and its biochemical basis. European J. Phycolog. 37(1):1-17. doi: 10.1017/s0967 026201003456.

Gypens, N., Borges, A.V. \& Lancelot, C., 2009. Effect of eutrophication on air-sea $\mathrm{CO} 2$ fluxes in the coastal Southern North Sea: a model study of the past 50 years. Global Change Biology, 15(4):1040-1056. doi: 10.1111/j.1365-248 6.2008.01773.x.

Howarth, R., Chan, F., Conley, D.J., Garnier, J., Doney, S.C., Marino, R. \& Billen, G., 2011. Coupled biogeochemical cycles: eutrophication and hypoxia in temperate estuaries and coastal marine ecosystems. Frontiers Ecol. Env., 9(1): 18-26. doi: 10.1890/1000 08.

Jin, K. R., \& Ji, Z. G., 2004. Case study: Modeling of sediment transport and wind-wave impact in
Lake Okeechobee. J. Hydraulic Eng. 130(11): 1055-1067. doi: 10.1061/(ASCE)0733-9429 (2004)130:11 (1055).

Kataki, S., West, H., Clarke, M. \& Baruah, D.C., 2016. Phosphorus recovery as struvite: Recent concerns for use of seed, alternative $\mathrm{Mg}$ source, nitrogen conservation and fertilizer potential. Res. Conserv. Recycling. 107:142156. doi : 10.1016/j.resconrec.2015.12.009.

Kress, N., Gertman, I. \& Herut, B., 2014. Temporal evolution of physical and chemical characteristics of the water column in the Easternmost Levantine basin (Eastern Mediterranean Sea) from 2002 to 2010. J. Mar. Sys. 135:6-13. doi: 10.1016/j.jmarsys. 2013.11.016.

Lau, W.W., 2013. Beyond carbon: Conceptualizing payments for ecosystem services in blue forests on carbon and other marine and coastal ecosystem services. Ocean Coast. Manag. 83:5-14. doi: 10.1016/j.ocecoaman.2012.03 .011.

Mehdiabadi. F.E., Mehdizabeh, M.M., \& Rahbani, M., 2015. Simulating Wind Driven Waves in the Strait of Hormuz using MIKE 21. Ind. J. Mar. Sci. 20(1):6-13. doi: 10.14710/ik.ijms.20. 1. 1-8.

Mustofa, A., 2015. Kandungan Nitrat dan Pospat sebagai Faktor Tingkat Kesuburan Perairan Pantai. Jurnal Disprotek, 6(1):13-19

Neale, P.J., Sobrino, C., Segovia, M., Mercado, J.M., Leon, P., Cortés, M.D., Tuite, P., Picazo, A., Salles, S., Cabrerizo, M.J. \& Prasil, O., 2014. Effect of $\mathrm{CO} 2$, nutrients and light on coastal plankton. I. Abiotic conditions and biological responses. Aqua. Biolog. 22: 25-41. doi: 10.33 54/ab00587.

Ondara, K. \& Wisha, U.J., 2016. Simulasi Numerik Gelombang (Spectral Waves) dan Bencana Rob Menggunakan Flexible Mesh dan Data Elevation Model Di Perairan Kecamatan Sayung, Demak. J. Kel.: Ind. J. Mar. Sci. Technol. 9(2):164-174. doi: 10.21107/jk.v9i 2.1694

Parihar, P., Singh, S., Singh, R., Singh, V.P. \& Prasad, S.M., 2015. Effect of salinity stress on plants and its tolerance strategies: a review. Environ. Sci. Poll. Res. 22(6):4056-4075. doi: 10.1007 /s11356-014-3739-1. 
Passy, P., Gypens, N., Billen, G., Garnier, J., Thieu, V., Rousseau, V., Callens, J., Parent, J.Y. \& Lancelot, C., 2013. A model reconstruction of riverine nutrient fluxes and eutrophication in the Belgian Coastal Zone since 1984. J. Mar. Sys. 128:106-122. doi: 10.1016/j.jmarsys. 2013.05.005.

Rabalais, N.N., Turner, R.E., Diaz, R.J. \& Justić, D., 2009. Global change and eutrophication of coastal waters. J. Mar. Sci. 66(7):1528-1537. doi: 10.1093/icesjms/ fsp047.

Redfield, A.C., 1934. On the proportions of organic derivatives in sea water and their relation to the composition of plankton. James Johnstone memorial volume, pp.176-192.

Risamasu, F.J. \& Prayitno, H.B., 2012. Kajian Zat Hara Fosfat, Nitrit, Nitrat dan Silikat di Perairan Kepulauan Matasiri, Kalimantan Selatan. Ind. J. Mar. Sci. 16(3):135-142.

Romero, E., Garnier, J., Lassaletta, L., Billen, G., Le Gendre, R., Riou, P. \& Cugier, P., 2013. Largescale patterns of river inputs in southwestern Europe: seasonal and interannual variations and potential eutrophication effects at the coastal zone. Biogeochem. 113(1-3):481-505. doi: $10.1007 /$ s10533-012-9778-0.

Rositasari, R., Setiawan, W.B., Supriadi, I.H. and Hasanuddin, P.B., 2007. Kajian dan Prediksi Kerentanan Pesisir Terhadap Perubahan Iklim: Studi Kasus di Pesisir Cirebon. J. IImu Teknol. Kel. Trop. 3(1):52-64.

Seitzinger, S.P., Mayorga, E., Bouwman, A.F., Kroeze, C., Beusen, A.H.W., Billen, G., Van Drecht, G., Dumont, E., Fekete, B.M., Garnier, J. \& Harrison, J.A., 2010. Global river nutrient export: A scenario analysis of past and future trends. Global Biogeochem. Cycles, 24(4):1-16 doi: 10.1029/2009gb003587.

Sewiko, R., 2016. Analisis Jejak Karbon Di Kawasan Wisata Pesisir Dan Laut (Studi Kasus Kawasan Wisata Pangandaran, Jawa Barat) (Doctoral dissertation, Bogor Agricutural University (IPB)).10p.

Simanjuntak, M., 2012. Sea Water Quality Observed from Nutrient Aspect, Dissolved Oxygen and Ph in the Banggai Waters, Central Sulawesi. J. IImu Teknol. Kel. Trop. 4(2):290-303. doi: 10.289 30/jitkt.v4i2.7791.
Susanto, R.D., Gordon, A.L. \& Zheng, Q., 2001. Upwelling along the coasts of Java and Sumatra and its relation to ENSO. Geophy. Res. Lett. 28(8):1599-1602. doi: 10.1029/2000g|0118 44 .

Thakur, R.K., Jindal, R., Singh, U.B. \& Ahluwalia, A.S., 2013. Plankton diversity and water quality assessment of three freshwater lakes of Mandi (Himachal Pradesh, India) with special reference to planktonic indicators. Environ. Monitoring and Assess. 185(10):8355-8373. doi: $10.1007 /$ s1 0661-013-3178-3.

Tungka, A.W., Haeruddin, H. and Ain, C., 2017. Concentration of Nitrate and Orthophosphate at Banjir Kanal Barat Estuary and their Relationship with the Abundance of Harmful Algae Blooms. Saintek Perikanan: Ind. J. Fish. Sci. Technol. 12(1):40-46. doi: 10.14710/ijfst . 12.1.40-46.

Utami, T.S., Hermansyah, H. and Nasikin, M., 2012. Biofiltration of nitrous oxide using cow-manure based compost as medium filter. J. Environ. Protec. 3(07):584-588. doi: 10.4236/jep.20 12.37070

van der Wulp, S.A., Damar, A., Ladwig, N. \& Hesse, K.J. 2016. Numerical simulations of River discharges, Nutrient flux and nutrient dispersal in Jakarta Bay, Indonesia. Mar. Poll. Bull. 110(2):.675-685. doi: 10.1016/j.marpolbul. 2016.05.015.

Wang, J. \& Liu, Y., 2013. Tourism-led land-use changes and their environmental effects in the southern coastal region of Hainan Island, China. J. Coast. Res. 29(5):1118-1125. doi: 10.2112/ jcoastres-d-12-00039.1.

Warren, I.R., \& Bach, H., 1992. MIKE 21: A Modelling System for Estuaries, Coastal Waters and Seas. Environ. Software. 7(4):229-240. doi: 10.10 16/0266-9838(92)90006-p.

Wisha, U.J. \& Heriati, A., 2016. Analisis Julat Pasang Surut (Tidal Range) dan pengaruhnya terhadap Sebaran Total Sedimen Tersuspensi (TSS) di Perairan Teluk Pare. J. Kel.: Ind. J. Mar. Sci. Technol. 9(1):23-31. doi: 10.21107/jk.v9i1. 1066.

Wisha, U.J., Husrin, S. and Prihantono, J., 2015. Hydrodynamics Banten Bay During Transitional 
Seasons (August-September)(Hidrodinamika Perairan Teluk Banten Pada Musim Peralihan (Agustus-September)). Ind. J. Mar. Sci. 20(2):101-112. doi: 10.14710/ik.ijms.20.2. 101-112.
Zhang, X., Wu, Y. \& Gu, B., 2015. Urban rivers as hotspots of regional nitrogen pollution. Environ. Poll. 205:139-144. doi: 10.1016/j.envpol. 2015.05.031. 